\title{
Improving the Oxidation Resistance and Electrical Properties of Ferritic Stainless Steels for Application in SOFC Interconnects
}

\author{
Aleksander Gil ${ }^{1} \cdot J$ Wyrwa ${ }^{1} \cdot$ Tomasz Brylewski $^{1}$
}

Received: 24 August 2015/Revised: 16 November 2015/Published online: 10 December 2015

(C) The Author(s) 2015. This article is published with open access at Springerlink.com

\begin{abstract}
The paper presents the results of cyclic oxidation studies performed for two ferritic stainless steels: Crofer 22 APU and H25T. The surface of the steels was coated with particles of oxides of the following active elements: yttrium, cerium, samarium, and gadolinium. Two coating methods were used: electrolysis and dip-coating. In addition, yttrium ion implantation was carried out for the purpose of reference. Cyclic oxidation tests were carried out for ca. $1200 \mathrm{~h}$ in air at $900{ }^{\circ} \mathrm{C}$. It was determined that particles of oxides of active elements reduce the rate of oxidation, improve the adhesion of the $\mathrm{Cr}_{2} \mathrm{O}_{3}$ scale to the substrate, and decrease area specific resistance.
\end{abstract}

Keywords Solid oxide fuel cell · Metallic interconnect · Reactive element effect · Ferritic stainless steel $\cdot$ Chromia scale

\section{Introduction}

Solid oxide fuel cells will not be popularized as a source of green energy in the small-scale power industry and in the motor industry if the manufacturing cost of these devices remains at an overly high level. For this reason, the reduction in production cost and the improvement of the durability of each fuel cell component are among the main objectives in this field.

Interconnects connect individual fuel cells in series, thus enabling the construction of energy sources in the form of stacks composed of multiple cells. There are usually several dozen fuel cells in a stack, and the voltage in such a source is equal to the sum of the voltages generated by individual cells. Interconnects serve several

Aleksander Gil

gil@agh.edu.pl

1 Faculty of Materials Science and Ceramics, AGH University of Science and Technology,

Al. Mickiewicza 30, 30-059 Krakow, Poland 
functions within a stack. The main function is providing electron transfer between the anode and the cathode that are part of neighbor cells. On each side of the interconnect, there is a system of channels that supply gas substrates (hydrogen and oxygen) to the anode and the cathode and remove the products of electrochemical oxidation (water vapor). Interconnects also serve as structural support for the cell, providing a certain level of mechanical stiffness [1,2].

Interconnects may be produced both from ceramic oxide materials that are characterized by high electron conductivity, such as perovskites [2], and from metal alloys [4-11]. The two main advantages of ceramic interconnects are their thermal expansion coefficient, which is similar to those of the other fuel cell components (i.e. the anode, the electrolyte, and the cathode), and their chemical inertness in relation to both the $\mathrm{H}_{2} / \mathrm{H}_{2} \mathrm{O}$ gas mixture and air. Since interconnects composed of oxide ceramics do not undergo corrosion degradation, the internal resistance within the source does not change during operation, allowing it to generate a constant level of power throughout its entire period of utilization. The main disadvantages of ceramic interconnects include high brittleness, susceptibility to thermal shocks, and their porosity, which, although not very pronounced, makes it impossible to achieve complete gas-tightness. Gas-tightness is a very desirable feature of the interconnect, since both fuel and an oxidant are always present on both of its sides. In addition, the manufacturing of ceramic interconnects is far more expensive than that of metallic interconnects, which prevents them from becoming popular. Interconnects composed of metal alloys are always gas-tight, and they exhibit incomparably better mechanical properties; unfortunately, the alloy components react with the anode and cathode gases, forming an oxide corrosion product on the surface. The oxide scale constantly increases in thickness during the operation of the source, which results in a gradual decrease in its power output.

Heat-resistant metal alloys that are coated with the protective $\mathrm{Al}_{2} \mathrm{O}_{3}$ scale cannot be used to manufacture metallic interconnects, because the electron conductivity of alumina is too low [7]. The only viable interconnect materials are thus alloys that form the protective $\mathrm{Cr}_{2} \mathrm{O}_{3}$ scale, including ferritic steels and chromium-based alloys; other metallic materials, such as austenitic steels and nickel-based alloys, exhibit overly high thermal expansion coefficients. Ferritic stainless steels are characterized by a thermal expansion coefficient that is slightly higher than that of chromium-based alloys, but it is still sufficiently low to allow them to operate along the other fuel cell components [2]. The low cost of ferritic steels is a major advantage.

At high temperatures, chromium oxide exhibits electron conductivity that is sufficiently high for the purpose of application in fuel cells; however, the electrical resistance of the interconnect may increase if the scale loses contact with the metallic substrate [3-8]. The loss of contact between the scale and the alloy is generally caused by changes in temperature, but it may also be observed at a constant temperature due to a phenomenon known as lateral growth [12]. The adhesion of $\mathrm{Cr}_{2} \mathrm{O}_{3}$ scales to iron-based, nickel-based, and cobalt-based metal alloys may be improved, and their growth rate reduced significantly, if an alloying addition in the form of a so-called active element (e.g. Y, La, Ce) is introduced [13-15]. This 
addition changes the predominant mass transport mechanism from the outward diffusion of chromium to the inward diffusion of oxygen [14].

The maximum amount of the active element that may be added to the alloy through metallurgic means is, however, limited by its natural solubility in the metallic phase. An alternative solution to the metallurgic method entails the introduction of active elements in the oxide form by means of mechanical alloying (MA) [16]. Such materials are known as oxide dispersed-strengthened (ODS) alloys [17]. This method allows the uniform distribution of active element nanoparticles throughout the entire volume of the alloy, which primarily improves its mechanical properties. The effectiveness of active elements in the form of dispersed oxides with regard to improving heat resistance is comparable with that of metallic additions, as demonstrated by the results of research on the high-temperature oxidation of ODStype alloys with various oxide additions: $\mathrm{Y}_{2} \mathrm{O}_{3}[18,19], \mathrm{La}_{2} \mathrm{O}_{3}$ [20], $\mathrm{CeO}_{2}$ [21], $\mathrm{Sm}_{2} \mathrm{O}_{3}$ [22], or $\mathrm{ThO}_{2}$ [23-26].

Interconnects composed of chromium-based ODS alloys were first manufactured in the early 1990s by the Austrian company Plansee. Studies of chromium-based ODS alloys containing dispersed $\mathrm{Y}_{2} \mathrm{O}_{3}$ particles showed that the heat resistance of these materials increases together with the degree of oxide phase fragmentation [27]. The scale that formed on chromium-based ODS alloys was composed entirely of chromia; at high temperatures, $\mathrm{Cr}_{2} \mathrm{O}_{3}$ reacts with $\mathrm{O}_{2}$ and $\mathrm{H}_{2} \mathrm{O}$, forming volatile chromium oxides and hydroxides $\left(\mathrm{CrO}_{3}, \mathrm{CrO}_{2}(\mathrm{OH})_{2}\right.$, etc. $)$ [28]. These compounds reacted with the $(\mathrm{La}, \mathrm{Sr}) \mathrm{MnO}_{4}$ perovskite that formed the cathode, resulting in the formation of the $(\mathrm{Cr}, \mathrm{Mn})_{3} \mathrm{O}_{4}$ spinel, which has less desirable catalytic properties than the perovskite. This undesirable effect was called "cathode poisoning" in the literature.

Further attempts to apply ODS alloys in the production of interconnects were aborted, but the knowledge and experience gained in the process turned out to be very useful when designing the chemical composition of the ferritic stainless steel known as the Crofer 22 APU, which is manufactured by the German corporation Thyssen-Krup VDM. Its production started based on the patent elaborated at Foschungszentrum Jülich by a group of scientists led by Quadakkers [29-35]. The composition of this steel was selected in such a way as to allow the formation of a double-layered scale on its surface; this scale would consist of an inner layer of $\mathrm{Cr}_{2} \mathrm{O}_{3}$ and an outer layer composed of the $\mathrm{MnCr}_{2} \mathrm{O}_{4}$ spinel. The outer layer was intended to prevent the formation of volatile chromium compounds.

The Crofer 22 APU steel contains a manganese addition of up to $0.8 \mathrm{wt} \%$. Manganese oxide, $\mathrm{MnO}$, is more thermodynamically stable than $\mathrm{Cr}_{2} \mathrm{O}_{3}$. However, due to the rapid diffusion of manganese in $\mathrm{Cr}_{2} \mathrm{O}_{3}$ and its high solubility in this oxide at temperatures higher than $800{ }^{\circ} \mathrm{C}$, the internal oxidation of manganese was not observed, but, instead, an outer spinel layer formed.

The Crofer 22 APU also contains a lanthanum addition of up to $0.2 \mathrm{wt} \%$. There was a reason for selecting lanthanum as an active element over yttrium, which had been the predominant element used for this purpose. Lanthanum reduces the growth rate of chromia the most effectively. The solubility of yttrium, cerium and zirconium in the $\alpha$-Fe base is below $0.1 \%$, and these elements also form intermetallic phases $\left(\mathrm{Fe}_{17} \mathrm{Y}_{2}, \mathrm{Fe}_{17} \mathrm{Ce}_{2}\right)$ with iron, and are bound as a result, leading to their reduced concentration in the solid solution. Lanthanum does not form 
intermetallic phases with iron, and, furthermore, its solubility in the $\alpha$-Fe phase is ca. five times higher. As a result, it is more effective as an active element.

The steel also contains a small amount of titanium, which is intended to increase the electron conductivity $\mathrm{Cr}_{2} \mathrm{O}_{3}$ via doping. Huczkowski et al. observed that the oxidation kinetics of the Crofer 22 APU steel depends on its thickness. Thinner samples were oxidized more rapidly. The accelerated kinetics were related to the faster depletion of the manganese and lanthanum reservoir in such samples [34].

The oxidation resistance of the alloys that form the protective $\mathrm{Cr}_{2} \mathrm{O}_{3}$ scale may be improved by adding the active element only to the surface layer of the material [36-38]. The method that is most suitable for this purpose is ion implantation, which allows any element to be introduced beneath the surface of a solid body in volumes that exceed its natural solubility [39]. Ion implantation is applied mostly in fundamental research, as it is a very costly technique when used in manufacturing. There are also certain limitations related to the geometry of the ion beam; it is impossible to implant the same dose of ions to elements with complex shapes.

An improvement in the oxidation resistance of the alloys that form the protective $\mathrm{Cr}_{2} \mathrm{O}_{3}$ scale may also be achieved via the deposition of a thin layer of active element oxides on the surface of the alloy. Ma et al. [40] demonstrated this for the Cr18-Ni9-Ti steel coated with a $\mathrm{Y}_{2} \mathrm{O}_{3}$ layer obtained by thermally decomposing yttrium hydroxide deposited on its surface via the electrolysis of an alcohol solution of yttrium nitrate.

The objective of the present paper was to improve the heat resistance of ferritic stainless steels by depositing thin layers of oxides of selected active elements on their surface. The material chosen for the study was the Crofer 22 APU steel. A part of the study also concerned the H25T steel manufactured in Poland by ArcelorMittal Poland Dąbrowa Górnicza. This steel contains manganese and titanium additions, but does not contain any active elements. Two methods were used to deposit the oxide layer: the electrochemical method described in paper [40], and the dip-coating technique. The oxides of the following metals were selected for the study: yttrium, cerium, samarium, and gadolinium. For comparison, ion implantation with yttrium ions at a dose of $2 \times 10^{16}$ at. $/ \mathrm{cm}^{2}$ was also applied. Cyclic oxidation tests were performed in air at $900{ }^{\circ} \mathrm{C}$. For selected samples, the area specific resistance (ASR) was measured in the temperature range of $475-800{ }^{\circ} \mathrm{C}$.

\section{Experimental Procedures}

The chemical composition of the Crofer 22 APU steel, as specified by the manufacturer, is presented in Table 1. The main alloy components of this steel are $\mathrm{Cr}, \mathrm{Mn}, \mathrm{Ti}$, and La, while the remaining elements should be considered impurities

Table 1 Chemical composition of the Crofer 22 APU steel (wt\%)

\begin{tabular}{llllllllllll}
\hline & $\mathrm{Fe}$ & $\mathrm{Cr}$ & $\mathrm{C}$ & $\mathrm{Mn}$ & $\mathrm{Si}$ & $\mathrm{Cu}$ & $\mathrm{Al}$ & $\mathrm{S}$ & $\mathrm{P}$ & $\mathrm{Ti}$ & $\mathrm{La}$ \\
\hline Min. & Bal. & 20.0 & 0.00 & 0.30 & 0.00 & 0.00 & 0.00 & 0.00 & 0.00 & 0.03 & 0.04 \\
Max. & & 24.0 & 0.03 & 0.80 & 0.50 & 0.50 & 0.50 & 0.02 & 0.05 & 0.20 & 0.20 \\
\hline
\end{tabular}


Table 2 Chemical composition of the H25T steel $(w t \%)$; $\mathrm{Ti}_{\min }=(4 \times \mathrm{C}), \mathrm{Ti}_{\max }=0.8 \%$ by PN-71/H86022

\begin{tabular}{lllllllllllllll}
\hline & $\mathrm{Fe}$ & $\mathrm{Cr}$ & $\mathrm{C}$ & $\mathrm{Mn}$ & $\mathrm{Si}$ & $\mathrm{Cu}$ & $\mathrm{Al}$ & $\mathrm{S}$ & $\mathrm{P}$ & $\mathrm{Ti}$ & $\mathrm{Ni}$ & $\mathrm{Mo}$ & $\mathrm{W}$ & $\mathrm{V}$ \\
\hline Min. & Bal. & 24 & 0.00 & 0.00 & 0.00 & 0.00 & 0.00 & 0.00 & 0.00 & 0.00 & 0.00 & 0.00 & 0.00 & 0.00 \\
Max. & 27 & 0.15 & 0.80 & 1.00 & 0.30 & 0.05 & 0.03 & 0.05 & 0.80 & 0.60 & 0.50 & 0.50 & 0.20 \\
\hline
\end{tabular}

introduced during the metallurgical process. The second alloy used in the study was the H25T ferritic steel, with the composition specified in Table 2. Unlike the Crofer 22 APU steel, H25T does not contain an active element; instead, it contains additions of Mo, W, V, and Ni alongside Mn and Ti.

The Crofer 22 APU steel was supplied in the form of a sheet with a thickness of $0.5 \mathrm{~mm}$, and the samples that were prepared from it for the purpose of cyclic oxidation studies had a size of $10 \times 20 \mathrm{~mm}^{2}$. On the other hand, the H25T steel came in the form of a cylinder with a diameter of $30 \mathrm{~mm}$. Discs with a thickness of $1 \mathrm{~mm}$ were first produced from this cylinder via turning, and then rectangular samples with the dimensions of $12 \times 10 \mathrm{~mm}^{2}$ were cut from these discs. The surfaces of all samples were polished until a mirror-like finish was achieved.

Three methods of modifying the steel's surface were applied in the study: the deposition of oxides of active elements via electrolysis, the deposition of oxides of active elements via dip-coating, and ion implantation.

In the electrolytic method, the modified alloy acted as the cathode, an alcohol solution of the nitrate of the selected element served as the electrolyte, while carbon felt was used as the anode. A stabilized power supply unit served as the power source. To avoid the contamination of solutions, a separate electrolytic system was prepared for each of them. Electrolytes of the following compounds were prepared: $\mathrm{Y}\left(\mathrm{NO}_{3}\right)_{3}, \mathrm{Ce}\left(\mathrm{NO}_{3}\right)_{3}, \mathrm{Gd}\left(\mathrm{NO}_{3}\right)_{3}$ and $\mathrm{Sm}\left(\mathrm{NO}_{3}\right)_{3}$ from analytical grade reagents supplied by Sigma Aldrich. Since these nitrates are only available in the aqueous form, the amount of each compound was chosen in such a way as to ensure that $250 \mathrm{~cm}^{3}$ of the corresponding electrolyte had a cation concentration of $0.01 \mathrm{M}$. The relevant data are presented in Table 3. To prepare the solutions, ethyl alcohol with low water content $(<0.2 \mathrm{wt} \%)$, supplied by Avantor Performance Materials Poland S.A., was used. Since the applied salts of rare earth elements were hydrated, the water content in the above-mentioned solution with a concentration of $0.01 \mathrm{M}$ increased by ca. $0.1 \mathrm{~g}$ per every $100 \mathrm{ml}$. The concentration of water in ethanol thus increases to ca. $0.3 \mathrm{wt} \%$.

The flow of current through the electrolyzer at the cathode (steel) caused metal to precipitate from the solution, according to the following reaction (this example is for yttrium):

$$
\mathrm{Y}^{3+}+3 \mathrm{e}^{\prime} \Leftrightarrow \mathrm{Y}^{\mathrm{o}}
$$

At the same time, the following reaction took place at the anode:

$$
2 \mathrm{H}_{2} \mathrm{O}+4 \mathrm{e}^{\prime} \Leftrightarrow \mathrm{O}_{2}+4 \mathrm{H}^{+}
$$


Table 3 Amounts of hydrated nitrates used for the preparation of solutions

\begin{tabular}{lllll}
\hline Reagent & $\mathrm{Y}\left(\mathrm{NO}_{3}\right)_{3} \times 6 \mathrm{H}_{2} \mathrm{O}$ & $\mathrm{Ce}\left(\mathrm{NO}_{3}\right)_{3} \times 6 \mathrm{H}_{2} \mathrm{O}$ & $\mathrm{Sm}\left(\mathrm{NO}_{3}\right)_{3} \times 6 \mathrm{H}_{2} \mathrm{O}$ & $\mathrm{Gd}\left(\mathrm{NO}_{3}\right)_{3} \times 6 \mathrm{H}_{2} \mathrm{O}$ \\
\hline $\begin{array}{c}\text { Amount }(\mathrm{g} / \\
\left.250 \mathrm{~cm}^{3}\right)\end{array}$ & 0.958 & 1.086 & 1.111 & 1.128 \\
\hline
\end{tabular}

Electrolysis was sustained for $30 \mathrm{~s}$, and the intensity of current was equal to $-10^{-3} \mathrm{~A}$. After the samples had been removed from the electrolyzer, they were immediately washed with pure alcohol to rinse off the remainder of the electrolyte. For the total sample surface area of $4.4 \mathrm{~cm}^{2}$, the current density was equal to $2.3 \times 10^{-4} \mathrm{~A} / \mathrm{cm}^{2}$. Based on current density and the time of electrolysis, it is possible to calculate the charge flowing through the system and, subsequently, the amount of active element that precipitated on the unit of the alloy's surface area:

$$
\mathrm{n}=\frac{\mathrm{N} \cdot \mathrm{j} \cdot \mathrm{t}}{\mathrm{F}}
$$

where $\mathrm{n}$ is the number of atoms $/ \mathrm{cm}^{2}, \mathrm{~N}$ is the Avogadro's number: $6.022 \times 10^{23}$ $(1 / \mathrm{mol}), \mathrm{j}$ is the current density $\left(\mathrm{A} / \mathrm{cm}^{2}\right), t$ is the electrolysis time (s) and $\mathrm{F}$ is the Faraday constant: $96500(\mathrm{C} / \mathrm{mol})$.

This value was equal to $4.06 \times 10^{16}$ at./ $/ \mathrm{cm}^{2}$ for each of the applied elements, which when taking into account mass corresponds to the following values: $2.1 \mu \mathrm{g} /$ $\mathrm{cm}^{2}$ for yttrium, $3.3 \mu \mathrm{g} / \mathrm{cm}^{2}$ for cerium, $3.6 \mu \mathrm{g} / \mathrm{cm}^{2}$ for samarium, and $3.7 \mu \mathrm{g} / \mathrm{cm}^{2}$ for gadolinium. It should, however, be emphasized that electrolysis in an ethanol medium that contains water is a very complex phenomenon, and in practice the amount of precipitated elements may be lower than the calculated theoretical values. The redox potential of water is more positive than that of rare earth elements, which is why water may also be reduced to gaseous hydrogen on the surface of the steel.

Since all of the above-mentioned elements exhibit very high reactivity and ethyl alcohol always contains a certain amount of water, the metal precipitating on the surface of the alloy entered into a reaction with the water, resulting in the formation of hydroxides. The following reaction involving yttrium is an example:

$$
Y+3 \mathrm{H}_{2} \mathrm{O} \Leftrightarrow Y(\mathrm{OH})_{3}+3 / 2 \mathrm{H}_{2}
$$

The solubility of the hydroxides of the above-mentioned elements in alcohol was low, and the samples were removed from the electrolyte just after electrolysis had finished. It may thus be assumed that the amount of hydroxide formed on the surface of the alloy was not significantly diminished due to dissolution. The next stage involved the thermal decomposition of the hydroxide layer, resulting in the formation of a layer composed of oxide particles on the surface of the alloy. The thermal decomposition was carried out for $1 \mathrm{~h}$ in air at $400{ }^{\circ} \mathrm{C}$.

The difficulty of obtaining a layer that has a uniform thickness across the entire surface of a sample with a complex shape is a major disadvantage of the electrolytic method. Carrying out electrolysis with the same current density at each point of the cathode surface - a prerequisite for achieving a uniform thickness of the deposited layer-is relatively easy only in the case of samples with a flat or cylindrical shape. 
It is much harder in the case of samples with a more developed surface, not to mention those featuring holes or channels in their internal structure, such as interconnects. For such samples, the thickness of the layer deposited via electrolysis will vary across the cathode's surface. It is for this reason that dip-coating was applied in the study. When using this method, the above-mentioned effect is negligible. If ethyl alcohol is used instead of water to prepare the salt solutions of active elements, it evaporates immediately upon the removal of the sample's part from the solution. As a result, the coating that had formed on the surface has the same thickness across the entire sample, even when the sample is complex in shape. The thickness of the coating is determined primarily by the density and viscosity of the solution, and the rate at which it is removed from the solution. A larger amount of a compound may be deposited by dipping and drying the sample multiple times; it should, however, be taken into account that during each subsequent dip a certain amount of the compound that had been deposited earlier may be dissolved. One of the ways to mitigate this effect is by dipping the sample a single time in a solution with a higher concentration.

To determine the mass of an element deposited per surface area unit of the material, an OPTIMA 7300 DV inductively coupled plasma optical emission spectrometer (ICP-OES) manufactured by Perkin Elmer was used. These investigations were performed for yttrium nitrate, which was deposited on the surface of a sample with the dimensions $20 \times 10 \times 0.5 \mathrm{~mm}^{3}$. The sample was then digested in a microwave mineralizer in spectrally pure nitric acid $(65 \%)$, at a temperature of $230{ }^{\circ} \mathrm{C}$, and under a pressure of $30 \mathrm{~atm}$. The measured amount of yttrium deposited on the surface area of $1 \mathrm{~cm}^{2}$ was equal to $3.5 \mu \mathrm{g}$. The same method was used to determine the mass of yttrium deposited on the surface of the steel via electrolysis. In this case, the measured mass was equal to $4.0 \mu \mathrm{g}$, which was approximately twice as high as the theoretical value calculated based on Faraday's law. Such a large discrepancy between these values might have been observed because a certain amount of the electrolyte had been trapped in the hydroxide sediment that had formed, despite the fact that the sample had been rinsed with pure ethanol after the completion of electrolysis. This would have happened if the deposited layer had been porous, and not compact.

Ion implantation was performed solely for the Crofer 22 APU steel; yttrium was implanted at a dose of $2 \times 10^{16}$ at. $/ \mathrm{cm}^{2}$ and with a beam energy of $70 \mathrm{keV}$. Based on the LSS theory [41], the effective range of yttrium atoms was determined to be $18 \mathrm{~nm}$, and its maximum intensity was established (16 at.\%).

Investigations of the size of oxide nanoparticles were performed by means of a Multimode 8 atomic force microscope (AFM) manufactured by Bruker. Observations of the morphology of the scales' surfaces were carried out using the NOVA NANO SEM 200 high-resolution scanning electron microscope manufactured by the FEI company. The furnace used for cyclic oxidation tests was positioned horizontally. During the experiments, the samples remained immobile, while the furnace was cyclically moved on rails by a computer-controlled stepper motor. The oxidation stage lasted $1 \mathrm{~h}$, while the samples remained outside the furnace for $15 \mathrm{~min}$. The samples were weighed once per day with an accuracy of $0.0001 \mathrm{~g}$ using an electric laboratory balance manufactured by Sartorius. 
The electrical resistance of pre-oxidized samples of the Crofer 22 APU steel was measured by means of the four-point two-probe method in air, over the range of $475-800{ }^{\circ} \mathrm{C}$, with a circuit with an external current source. The current drop for each sample was measured by means of an HP digital multimeter (34401) with $0.3 \%$ precision. A sample with the dimension of $10 \times 10 \mathrm{~cm}^{2}$ and a silver electrode with a diameter of $5 \mathrm{~mm}$ deposited on both sides was placed between flat platinum electrodes and then heated in an electric furnace until the desired temperature was achieved.

Sample resistance was recorded at the given temperature every $10 \mathrm{~min}$. The temperature was then increased by $25 \mathrm{~K}$ and the sample was equilibrated at this increased temperature for $1 \mathrm{~h}$. The apparatus used to measure the electrical resistance and the sample preparation procedure are described in Ref. [42]. The electrical resistance of an oxidized specimen is usually measured in terms of its area specific resistance (ASR), which is defined as the product of resistance and the nominal contact surface area of the oxide and the steel. Due to the symmetrical design of the sample, the area specific resistance of the samples was calculated based on the obtained resistance values using the following formula:

$$
\mathrm{ASR}=\frac{\mathrm{R} \cdot \mathrm{A}}{2}
$$

where $\mathrm{R}$ is electrical resistance $[\Omega]$ and $\mathrm{A}$ is the surface area of the Pt layer $\left(\mathrm{cm}^{2}\right)$.

\section{Results and Discussion}

The size of these particles can only be established if they are deposited on an inert substrate that does not react with oxygen at high temperatures. One of the materials that is suitable for this purpose is float glass. Since glass acts as an insulator, the dipcoating method was the only method that could be used to determine the size of the above-mentioned particles. These samples were examined by means of atomic force microscopy. The scanned area had dimensions of $200 \times 200 \mathrm{~nm}^{2}$ (Fig. 1). The size of $\mathrm{Y}_{2} \mathrm{O}_{3}$ particles determined based on these measurements was of the order of several dozen nanometers. These studies demonstrate that oxide particles obtained via the thermal decomposition of nitrates are similar in size to oxide particles in ODS alloys, which are produced by means of the MA method.

Figure 2 presents the results of cyclic oxidation studies carried out for the uncoated Crofer 22 APU steel, for the steel with $\mathrm{Y}_{2} \mathrm{O}_{3}$ particles deposited by means of either electrolysis or dip-coating, and for the steel after implantation with yttrium ions at a dose of $2 \times 10^{16}$ at. $/ \mathrm{cm}^{2}$. The test comprised around 12001 -h cycles. As expected, the deposition of $\mathrm{Y}_{2} \mathrm{O}_{3}$ particles had a less pronounced effect than yttrium ion implantation. The mass gain in the case of the steel samples coated with yttria particles was only $30 \%$ lower than that observed for uncoated steel, as opposed to the $60 \%$ reduction in mass gain observed in the case of the material implanted with yttrium ions.

Figure 3 shows the cross-sections of the uncoated sample and the sample after yttrium ion implantation, and the surface morphology of the scales corresponding to these samples. In both cases, an internal oxidation zone comprising fine oxide 


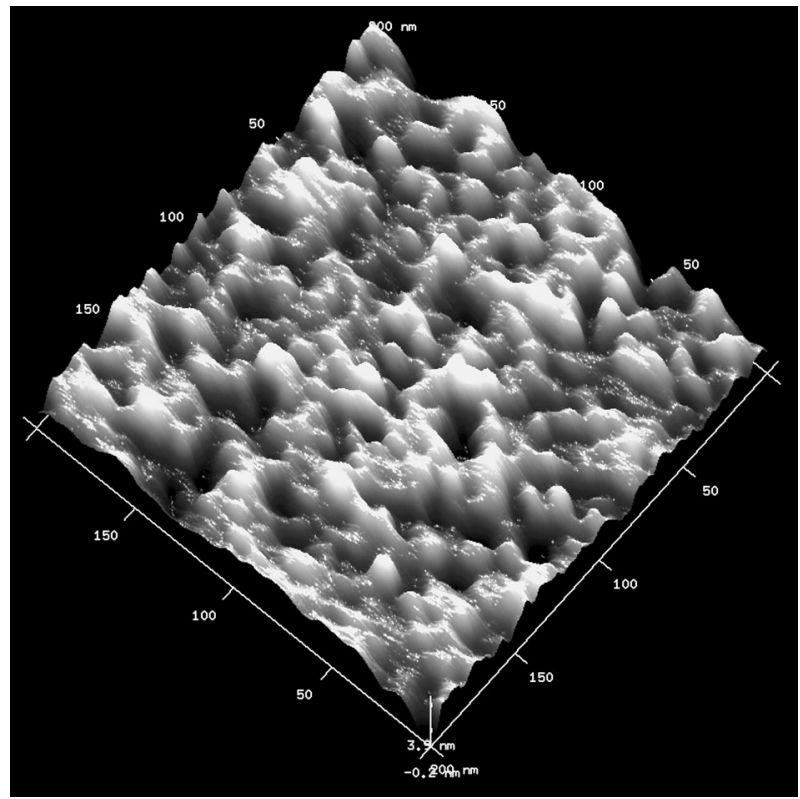

Fig. 1 AFM image of an $\mathrm{Y}_{2} \mathrm{O}_{3}$ film deposited on the surface of glass

Fig. 2 Cyclic oxidation conditions for different Crofer 22 APU samples: unmodified and modified with yttrium by means of various methods; Y-impl. (ion implantation), Y-el. (deposited $\mathrm{Y}_{2} \mathrm{O}_{3}$ particleselectrolysis), Y-dip. (deposited $\mathrm{Y}_{2} \mathrm{O}_{3}$ particles-dip-coating)

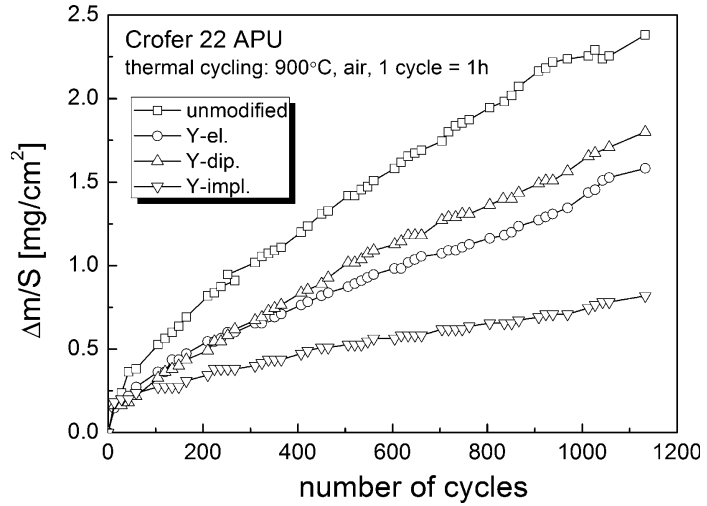

precipitates had formed within the metallic phase beneath the scale. A similar internal oxidation zone was observed in the case of the steel samples modified with $\mathrm{Y}_{2} \mathrm{O}_{3}$ particles. The numerous studies conducted for the Crofer 22 APU steel by other authors indicate that oxides of metals that constitute impurities, mainly silicon and aluminum, are formed within this zone. The depth of the internal oxidation zone was practically the same in the case of all studied samples, including the uncoated steel, due to the fact that this depth is not determined by the thickness of the scale layer that is in direct contact with the metallic phase, but by the partial pressure of oxygen. Although the scales formed on different samples varied in thickness, the 
Fig. 3 Cross-sections, surface morphology and EDS-spectra of Crofer 22 APU steel samples after cyclic oxidation: a, c, eunmodified, b, d, f-implanted $\left(2 \times 10^{16} \mathrm{Y} / \mathrm{cm}^{2}\right)$
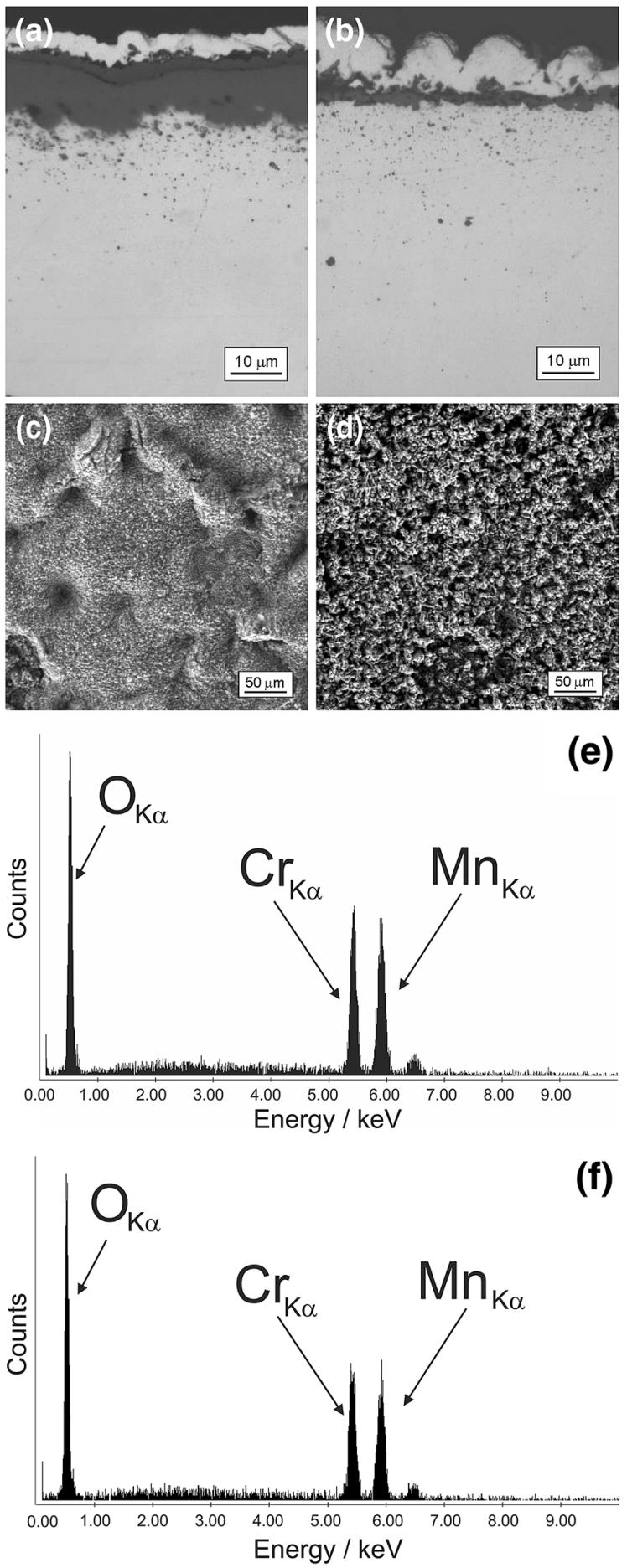
$\mathrm{MnCr}_{2} \mathrm{O}_{4}$ spinel was always present on the surface of these scales. This is indicated by the results of chemical composition studies carried out by means of the EDS method. As evident in the case of the uncoated sample and the sample after yttrium ion implantation, the EDS spectra feature pronounced peaks corresponding to $\mathrm{Cr}_{\mathrm{K} \alpha}$, $\mathrm{Mn}_{\mathrm{K} \alpha}$ and $\mathrm{O}_{\mathrm{K} \alpha}$ (Fig. 3). Observations of the surfaces of the scales formed on the samples after ca. $1200 \mathrm{~h}$ of cyclic oxidation revealed cracks and minor scale spallation only on the uncoated alloy.

All obtain cyclic oxidation curves (Fig. 2) indicate monotonic mass gain. This type of character of mass changes in the samples does not lead to any conclusions as to whether modifying the surface of the Crofer 22 APU steel with yttria particles improves the adhesion of the scale in addition to reducing its rate of growth. However, this can be proven indirectly, by conducting cyclic oxidation studies for an alloy with a similar chemical composition, but without the addition of any active elements. The H25T heat-resistant steel, which meets these requirements, was selected for this purpose. Both the Crofer 22 APU and the H25T have a very high chromium content, i.e. over $20 \mathrm{wt} \%$. Consequently, this element undergoes selective oxidation in a wide range of temperatures and oxygen partial pressures, forming a protective $\mathrm{Cr}_{2} \mathrm{O}_{3}$ scale. Both steels also contain a manganese addition of up to $0.8 \mathrm{wt} \%$, although the reasons for making this addition were different. In the case of the Crofer 22 APU, manganese was used in order to promote the formation of the $\mathrm{MnCr}_{2} \mathrm{O}_{4}$ spinel on the surface of the $\mathrm{Cr}_{2} \mathrm{O}_{3}$ scale. The spinel's intended function was to prevent the oxidation of chromia to volatile oxides and hydroxides. On the other hand, the manganese addition to the H25T steel was made in order to reduce the amount of sulphur and oxygen during the smelting process.

Another addition that is common for both steels is titanium. In the Crofer 22 APU steel, the titanium addition is responsible for improving the electron conductivity of chromia via doping. In the H25T steel, titanium prevents grain growth, which occurs rapidly above $950{ }^{\circ} \mathrm{C}$. This comparison shows that a given alloying addition may cause several effects with different mechanisms of action.

The H25T steel also contains small amounts of Mo, W, V, and Ni; these additions improve the mechanical properties of this steel, and do not significantly affect the oxidation kinetics. Oxygen partial pressures of oxides of these elements are higher than that of chromia. Consequently, none of these oxides should form in the internal oxidation zone beneath the $\mathrm{Cr}_{2} \mathrm{O}_{3}$ scale. The $\mathrm{H} 25 \mathrm{~T}$ steel is thus a suitable reference material in relation to the Crofer 22 APU steel, and it can be used to examine how particles of active element oxides affect the adhesion of the $\mathrm{Cr}_{2} \mathrm{O}_{3}$ scale.

The obtain mass change curves for the H25T steel with yttria particles deposited via electrolysis and without this modification are presented in Fig. 4. In this case, the cyclic oxidation test lasted $600 \mathrm{~h}$. After this time, the mass loss of the unmodified material exceeded $0.6 \mathrm{~g} / \mathrm{cm}^{2}$, which corresponded to approximately half of the maximum mass gain of the sample, which was observed around the 200th heating cycle. The character of the cyclic oxidation curve for the H25T steel is typical for materials that form scales with moderate adhesion to the metallic phase. In the case of alloys that form scales with extremely poor adhesion, mass loss is observed as early as after the first oxidation cycle. 
Fig. 4 Cyclic oxidation of $\mathrm{H} 25 \mathrm{~T}$ steel samples, unmodified and modified with $\mathrm{Y}_{2} \mathrm{O}_{3}$ particles (electrolysis)
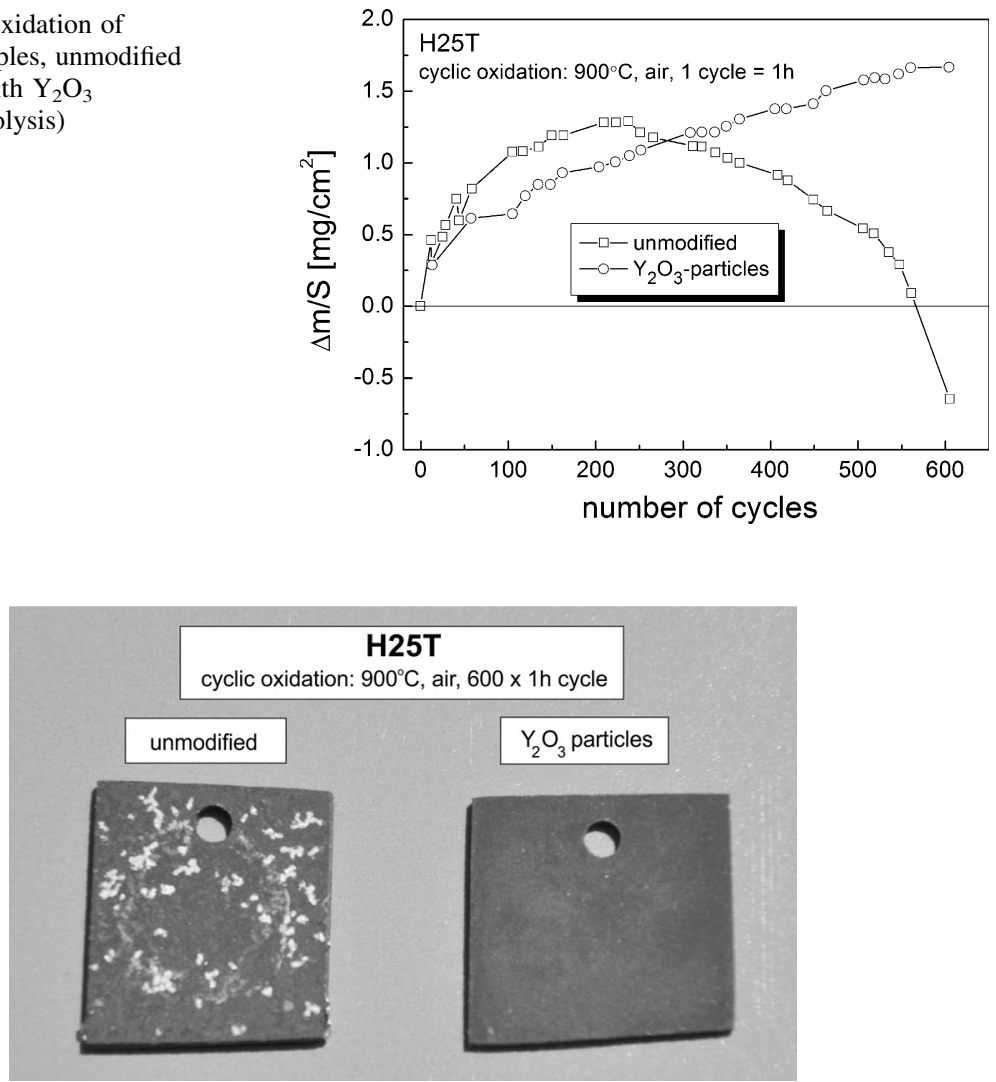

Fig. $5 \mathrm{H} 25 \mathrm{~T}$ steel samples after cyclic oxidation; left: unmodified steel, right: steel with deposited $\mathrm{Y}_{2} \mathrm{O}_{3}$ particles (electrolysis)

The mass change curve recorded for the steel modified with $\mathrm{Y}_{2} \mathrm{O}_{3}$ particles had a different shape. The monotonic mass gain indicates the lack of scale spallation, which was also confirmed by means of microscopic examinations. Figure 5 shows the samples of the H25T alloy after the completion of the cyclic oxidation study; its left side shows the unmodified sample, and the right one presents the sample modified with $\mathrm{Y}_{2} \mathrm{O}_{3}$ particles. The white spots on the surface of the unmodified steel sample indicate locations at which oxide scale fragments had undergone complete spallation, exposing the shining metallic substrate. On the surface of this sample, grey spots are also visible. These indicate areas at which the scale had lost adhesion earlier, and at which the exposed metal was coated with another oxide layer. On the other hand, scale spallation was not observed for the H25T steel sample modified with yttria particles. This proves that this modification can improve the adhesion of the $\mathrm{Cr}_{2} \mathrm{O}_{3}$ scale to the metallic substrate.

The results of cyclic oxidation studies carried out for the Crofer 22 APU steel with particles of oxides of selected lanthanides (cerium, samarium, and gadolinium) deposited via electrolysis are presented in Fig. 6. When comparing these curves 
Fig. 6 Cyclic oxidation of Crofer 22 APU steel, unmodified and modified with oxide particles of selected lanthanides

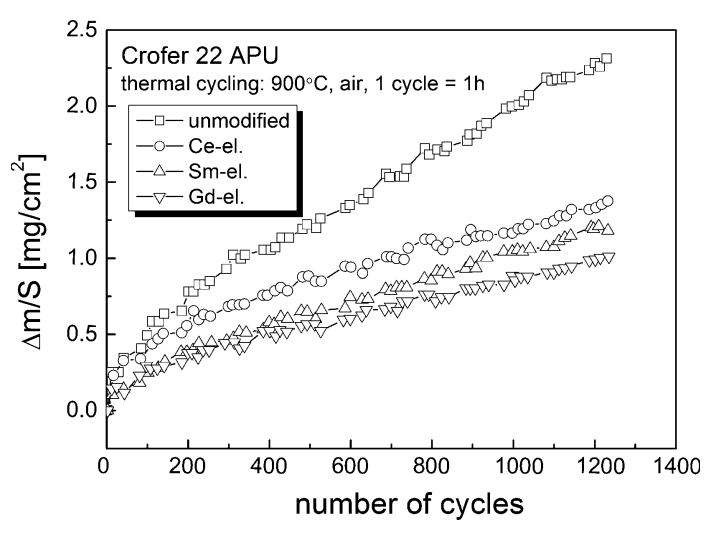

with the one obtained for yttria (Fig. 2), it is clear that oxides of lanthanides are more effective than yttria. The lowest mass gain was observed for the steel sample modified with $\mathrm{Gd}_{2} \mathrm{O}_{3}$ particles. In this case, it was ca. $55 \%$ lower than that for unmodified steel. Figure $7 \mathrm{a}-\mathrm{c}$ show the cross-sections of these samples as well as the surface morphologies of the corresponding scales (Fig. 7d-f) together with EDS spectra (Figs. $7 \mathrm{~g}-\mathrm{i}$ ). As in the case of the steel sample modified with yttria particles, the scale exhibited a double-layered structure with an inner layer composed of $\mathrm{Cr}_{2} \mathrm{O}_{3}$ and an outer layer consisting of the $\mathrm{MnCr}_{2} \mathrm{O}_{4}$ spinel.

As in the case of yttria, two methods of oxide particle generation were applied for oxides of lanthanides: electrolysis and dip-coating. The results of cyclic oxidation studies for the steel samples coated via these methods are shown in Figs. 8, 9, and 10. As can be seen, these curves were similar to one another, which indicates similar effectiveness. The main advantage offered by the dip-coating technique is the possibility of coating elements with complex shape.

The effect of rare earth elements on alloys forming protective $\mathrm{Cr}_{2} \mathrm{O}_{3}$ scales is attributed to segregation to grain boundaries in chromia. A higher concentration of yttria at grain boundaries in the $\mathrm{Cr}_{2} \mathrm{O}_{3}$ was first reported by Przybylski et al. [14] based on STEM observations involving an EDX detector. These studies concerned the $\mathrm{Cr}_{2} \mathrm{O}_{3}$ scale formed on the $\mathrm{Co}-40 \mathrm{Cr}$ alloy, which had been implanted with yttrium ions at a dose of $10^{16}$ at. $/ \mathrm{cm}^{2}$. The ion beam of yttrium is ca. $35 \%$ larger than the ion beam of chromium. As a result, yttrium has a strong tendency to accumulate around chromia grain boundaries. It is also assumed that the $\mathrm{YCrO}_{3}$ perovskite forms at grain boundaries [43].

The maximum level of an active element addition in an alloy is limited by its natural solubility in the solid phase. Controlling this concentration in mass-produced alloys is very difficult from a technological point of view. This is demonstrated by the fluctuations in the content of some alloy components reported by manufacturers in the certification materials for their products. This is also true of both steels investigated in the present study (Tables 1,2).

Implantation with ions of active elements is very effective at improving the oxidation resistance of alloys that form protective $\mathrm{Cr}_{2} \mathrm{O}_{3}$ scales. The reason for this 

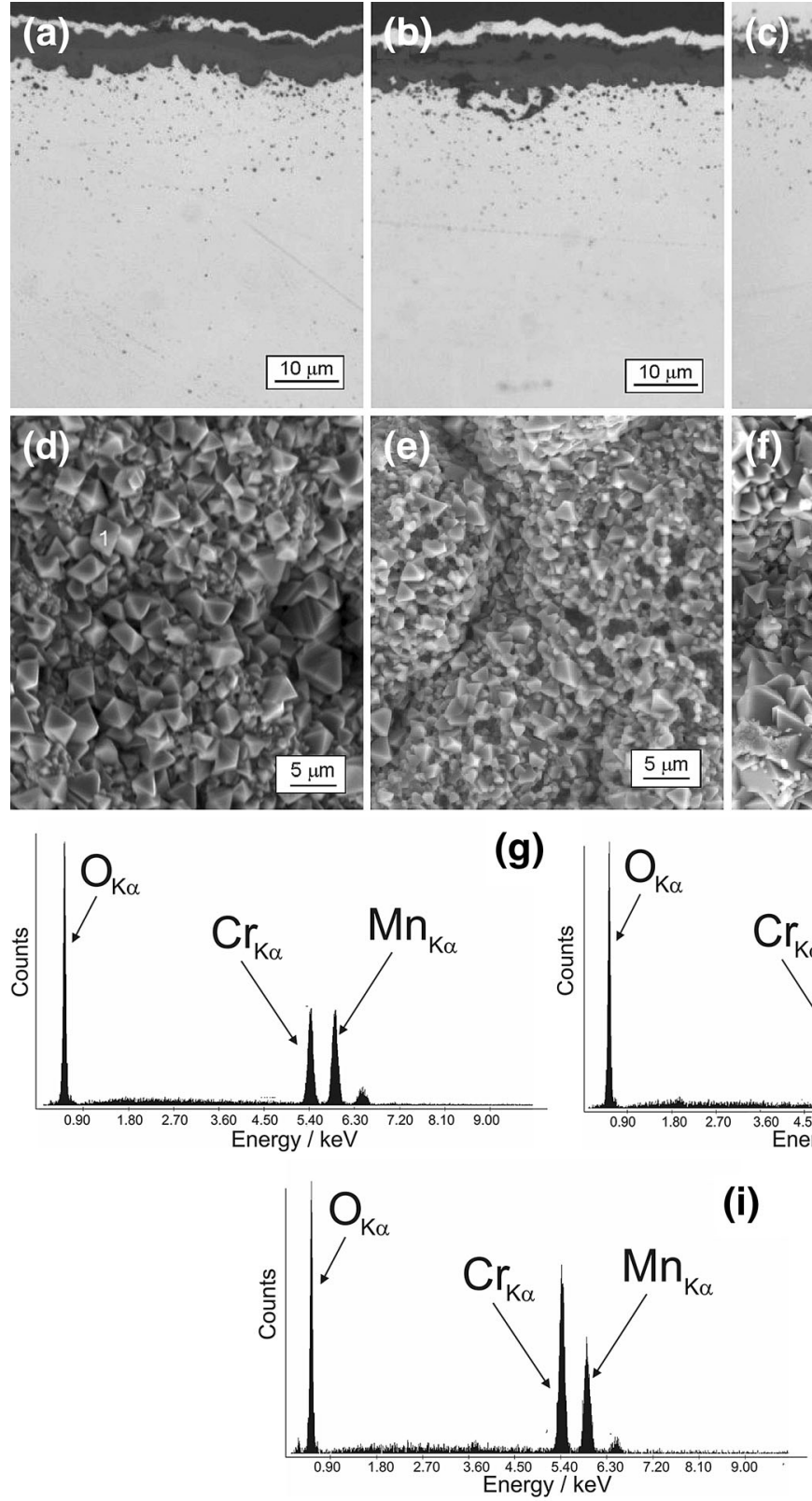

(i)
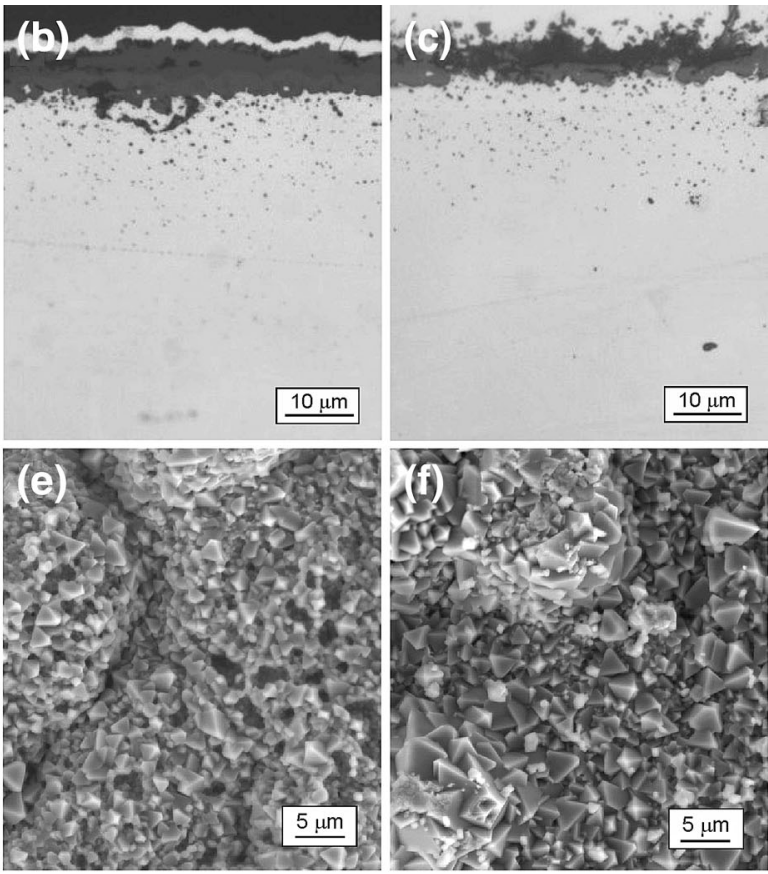

(h)

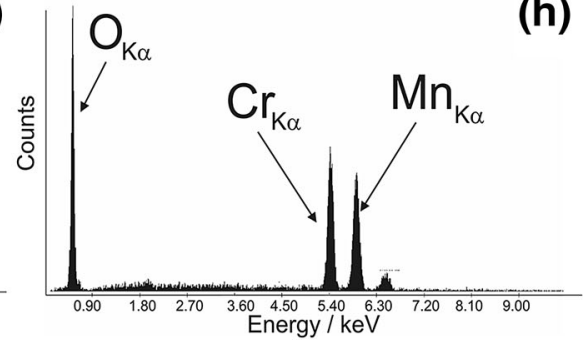

Fig. 7 Cross-sections, surface morphologies and EDS spectra from the scale formed on the Crofer 22 APU steel, with the deposited particles of selected lanthanides (electrolysis) (thermal cycling: $900{ }^{\circ} \mathrm{C}$, air, $1250 \times 1$ h cycle): $\mathbf{a}, \mathbf{d}, \mathbf{g}$-cerium oxide, $\mathbf{b}, \mathbf{e}, \mathbf{h}-$ samarium oxide, $\mathbf{c}, \mathbf{f}, \mathbf{i}$-gadolinium oxide 
Fig. 8 Cyclic oxidation of the Crofer 22 APU steel with deposited cerium oxide particles (Ce-el.-electrolysis, Ce-dip.dip-coating); dashed line-the curve for unmodified steel

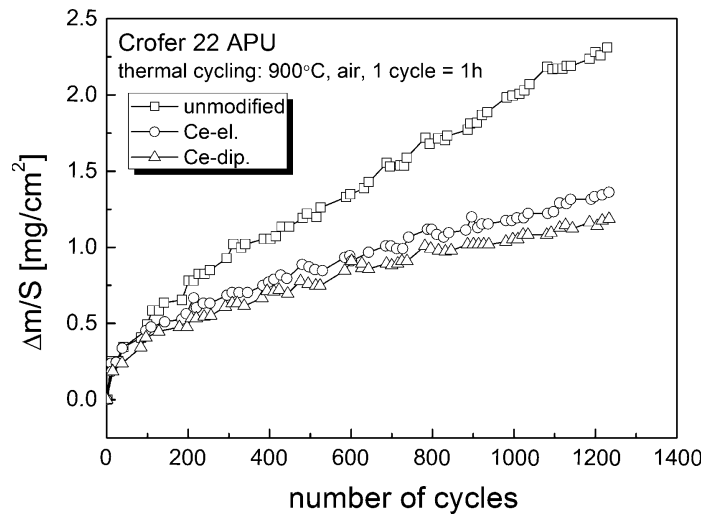

Fig. 9 Cyclic oxidation of the Crofer 22 APU steel with deposited samarium oxide particles (Sm-el._electrolysis, Sm-dip.-dip-coating); dashed line - the curve for unmodified steel

Fig. 10 Cyclic oxidation of the Crofer 22 APU steel with deposited gadolinium oxide particles (Gd-el.-electrolysis, Gd-dip.-_dip-coating); dashed line-the curve for unmodified steel
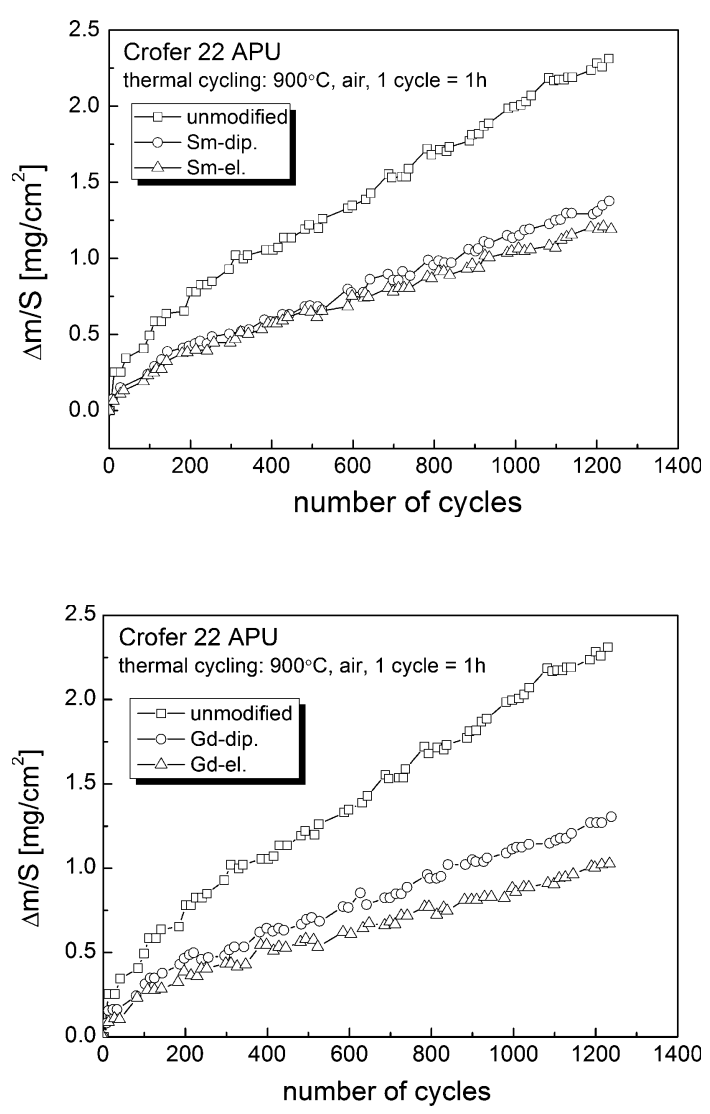

is that atoms the active element are located just underneath the surface of the alloy (usually at a depth of up to $20 \mathrm{~nm}$ ), and they are present in very large concentrations, of the order of a dozen or so at.\% Consequently, even at the oxide 
nucleate growth stage, atoms of the active element are capable of complete incorporation into the oxide. In the case of the Crofer 22 APU steel, the surface concentration of lanthanum at the start of the oxidation process may be as high as $0.2 \mathrm{wt} \%$. It should be added that after the formation of the $\mathrm{Cr}_{2} \mathrm{O}_{3}$ layer, the active elements starts to undergo internal oxidation. The deposition of particles of active element oxides with a size of several dozen $\mathrm{nm}$ on the surface of the alloy that already contains an active element makes it possible to further enlarge the reservoir of the active element within the scale. Particles that are this small are also absorbed by chromia at the early stage of oxidation.

From a practical point of view, it is important that the reduction of the rate of the scale's growth on the interconnect materials is accompanied by a decrease in its electrical resistance. The latter property is affected not only by the scale's thickness, but also by its adhesion to the metallic substrate. To demonstrate this, ASR measurements were performed over a wide range of temperatures that corresponds to the operating conditions of intermediate-temperature solid oxide fuel cells (ITSOFCs). Samples of the Crofer 22 APU steel, unmodified, modified with yttria particles deposited via electrolysis, and implanted with yttrium ions, were preoxidized for $100 \mathrm{~h}$ in air at $900{ }^{\circ} \mathrm{C}$. A silver contact layer was then deposited on the surface of the scales that had formed, after which resistance was measured over the range of $475-800{ }^{\circ} \mathrm{C}$. The influence of the contact layer on the mass transport mechanism in the $\mathrm{Cr}_{2} \mathrm{O}_{3}$ scale was thus kept at a minimum. This phenomenon is observed in the case of long-term measurements of conductivity, especially for the Pt contact layer [44, 45].

Temperature dependences of area specific resistance (ASR) for the examined samples in an Arrhenius plot are presented in Fig. 11, while their values at $800{ }^{\circ} \mathrm{C}$ are collected in Table 4. These plots demonstrate that the logarithm of ASR increases linearly with decreasing temperature; such tendency is typical for semiconductors, such as chromia. The smaller inclination of the line corresponding to the steel with implanted yttrium ions may likely be due to the reduction in $\mathrm{Cr}_{2} \mathrm{O}_{3}$ grain size and the related increased density of intergrain boundaries in this scale. Of the

Fig. 11 Sample ASR versus temperature in an Arrhenius plot

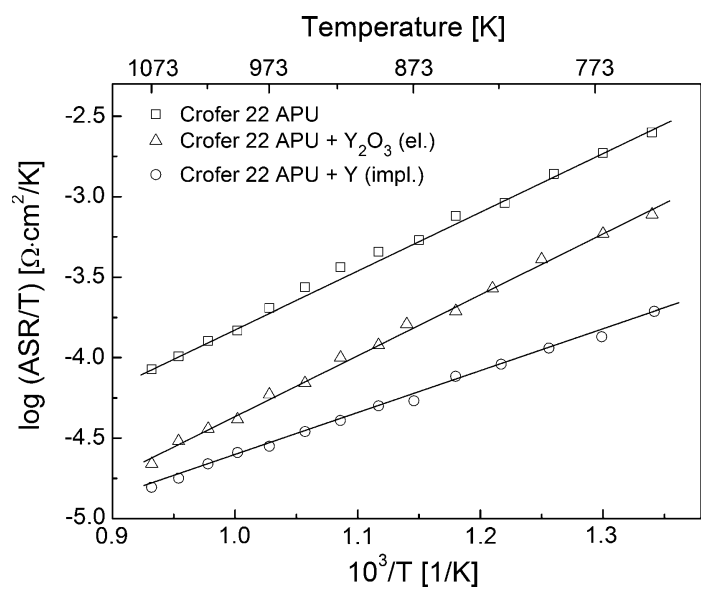


Table 4 ASR values at $800{ }^{\circ} \mathrm{C}$

\begin{tabular}{ll}
\hline Material & ASR $\left(\Omega \mathrm{cm}^{2}\right)$ \\
\hline Crofer 22 APU & 0.0911 \\
Crofer 22 APU $+\mathrm{Y}_{2} \mathrm{O}_{3}(\mathrm{el})$. & 0.0235 \\
Crofer 22 APU $+\mathrm{Y}$ (impl.) & 0.0168 \\
\hline
\end{tabular}

steel samples that had undergone surface modification, the lowest ASR value, i.e. $0.0168 \Omega \mathrm{cm}^{2}$ at $800{ }^{\circ} \mathrm{C}$, was observed for the steel implanted with yttrium ions. An intermediate ASR value $\left(0.0235 \Omega \mathrm{cm}^{2}\right)$ was obtained for the Crofer 22 APU sample with the layer deposited via electrolysis, while the highest one was observed in the case of the unmodified steel $\left(0.0911 \Omega \mathrm{cm}^{2}\right)$.

\section{Conclusions}

Based on the obtained result, the following conclusions may be made:

1. The effect of active element additions in the case of the Crofer 22 APU ferritic stainless steel may be amplified by increasing the concentration of the active element in the surface layer of the material either via ion implantation or via the deposition of particles of the corresponding active element oxides.

2. Particles of oxides of lanthanides were more effective at improving the oxidation resistance of the Crofer 22 APU steel than yttria.

3. $\mathrm{Y}_{2} \mathrm{O}_{3}$ particles deposited on the surface of the $\mathrm{H} 25 \mathrm{~T}$ steel that does not contain any active element additions yield a long-term improvement in the adhesion of the $\mathrm{Cr}_{2} \mathrm{O}_{3}$ scale.

4. The phase composition of scales formed on the two investigated ferritic stainless steels did not change after modification with particles of oxides of active elements; the main oxide phases are $\mathrm{Cr}_{2} \mathrm{O}_{3}$ and $\mathrm{MnCr}_{2} \mathrm{O}_{4}$, with the former constituting the inner layer, and the latter-the outer one.

5. When deposited on the surface of the Crofer 22 APU steel, particles of oxides of active elements reduce the area specific resistance (ASR) of the corrosion product that forms on the steel.

Acknowledgments The authors kindly acknowledge support from the European Institute of Innovation and Technology (EIT). The study was performed as part of the EIT KIC InnoEnergy project "New Materials for Energy Systems". The authors would also like to thank Wiesław Knap from the Department of Hydrogeology and Geological Engineering at the AGH UST Faculty of Geology, Geophysics and Environmental Protection for performing the ICP-OES analysis.

Open Access This article is distributed under the terms of the Creative Commons Attribution 4.0 International License (http://creativecommons.org/licenses/by/4.0/), which permits unrestricted use, distribution, and reproduction in any medium, provided you give appropriate credit to the original author(s) and the source, provide a link to the Creative Commons license, and indicate if changes were made. 


\section{References}

1. N. Q. Minh and T. Takahashi, Science and Technology of Ceramic Fuel Cells, (Elsevier, Amsterdam, 1995).

2. S. C. Singhal and K. Kendall, eds. High Temperature Solid Oxide Fuel Cells: Fundamentals, Design and Applications (Elsevier, Kidlington Oxford, 2003).

3. W. J. Quadakkers, J. Piron-Abellan, V. Shemet and L. Singheiser, Materials at High Temperatures 20, 2003 (115).

4. T. Kadowaki, T. Shiomitsu, E. Matsuda, H. Nakagawa, H. Tsuneizumi and T. Maruyama, Solid State Ionics 67, 65 (1993).

5. K. Huang, P. Y. Hou and J. B. Goodenough, Solid State Ionics 129, 237 (2000).

6. T. Brylewski, M. Nanko, T. Maruyama and K. Przybylski, Solid State Ionics 143, 131 (2001).

7. J. W. Fergus, Materials Science and Engineering 397, 271 (2005).

8. W. Z. Zhu and S. C. Deevi, Materials Research Bulletin 38, 957 (2003).

9. T. Brylewski, A. Gil, A. Rakowska, S. Chevalier, A. Adamczyk, J. Dąbek, A. Kruk, M. Stygar and K. Przybylski, Oxidation of Metals 80, 83 (2013).

10. T. Brylewski, J. Dąbek, K. Przybylski, J. Morgiel and M. Rękas, Journal of Power Sources 208, 86 (2012).

11. P. Piccardo, R. Amendola, S. Fontana, S. Chevalier, G. Caboches and P. Gannon, Journal of Applied Electrochemistry 39, 545 (2009).

12. F. A. Golightly, F. H. Stott and G. C. Wood, Oxidation of Metals 10, 163 (1976).

13. P. Kofstad, High Temperature Corrosion, (Elsevier Aplied Science, Essex, 1988).

14. K. Przybylski and G. J. Yurek, Materials Science Forum 43, 1 (1989).

15. G. Bonnet, M. Silva, S. Chevalier, J. P. Larpin and J. C. Colson, Surface and Coatings Technology 80, 76 (1996).

16. J. S. Benjamin, Metallurgical Transactions 1, 2943 (1970).

17. P. Gilman and J. S. Benjamin, Nickel- and Iron-Based Dispersion Strengthened Alloys, Powder Metallurgy, Vol. 7, ASM Handbook, vol. 7, (American Society for Metals, Metals Park, 1985), p. 722.

18. J. Stringer and I. G. Wright, Oxidation of Metals 5, 59 (1972).

19. J. Stringer, B. A. Wilcox and R. I. Jaffee, Oxidation of Metals 5, 11 (1972).

20. H. T. Michels, Metallurgical Transactions 7A, 379 (1976).

21. I. G. Wright, B. A. Wilcox and R. I. Jaffee, Oxidation of Metals 9, 275 (1975).

22. J. Stringer and A. Z. Hed, Oxidation of Metals 3, 571 (1971).

23. H. H. Davis, H. C. Graham and I. A. Kvernes, Oxidation of Metals 3, 432 (1971).

24. C. S. Giggns and F. S. Pettit, Metallurgical Transactions 2, 1071 (1971).

25. C. E. Lowel, Oxidation of Metals 5, 11 (1972).

26. C. E. Lowel and W. A. Sanders, Oxidation of Metals 5, 221 (1972).

27. A. Gil, H. J. Penkalla, M. Hänsel, J. Norton, W. Köck, W. J. Quadakkers, Proceedings of IX Conference on Electron Microscopy o Solids (Zakopane, Poland, May 6-9, 1996) p. 441.

28. K. Hilpert, D. Das, M. Miller, D. H. Peck and R. Weiß, Journal of the Electrochemical Society 143, 3642 (1996).

29. J. Piron-Abellan and W. J. Quadakkers, Report Forschungszentrum Juelich, Jül-4170, March 2005, ISSN 0944-2952.

30. W. J. Quadakkers, J. Piron-Abellan, V. Shemet and L. Singheiser, Materials Research 7, 203 (2004).

31. R. Hojda, W. Heimann, and W. J. Quadakkers, Großserientaigliches Werkstoffkonzept für Hochtemperatur-Brennstoffzellen, TyssenKrupp-Techforum, (2003), p. 20.

32. P. Huczkowski, N. Christiansen, V. Shemet, J. Piron-Abellan, L. Singheiser and W. J. Quadakkers, Journal of Fuel Cell Science and Technology 1, 30 (2004).

33. P. Huczkowski, N. Christiansen, V. Shemet, J. Piron-Abellan, L. Singheiser and W. J. Quadakkers, Materials and Corrosion 55, 825 (2004).

34. P. Huczkowski, S. Ertl, J. Piron-Abellan, N. Christiansen, T. Höfler, V. Shemet, L. Singheiser and W. J. Quadakkers, Materials at High Temperatures 22, 79 (2005).

35. W. J. Quadakkers and L. Singheiser, Material Science Forum 369-372, 77 (2001).

36. K. Przybylski and S. Mrowec, Proceedings of 9th International Congress on Metallic Corrosion, June 3-7, (Toronto, Canada, 1984, vol. 1), p. 47.

37. J. Jedliński and S. Mrowec, Materials Science and Engineering 87, 281 (1987).

38. S. Mrowec, A. Gil and J. Jedliński, Werkstoffe und Korrosion 38, 563 (1987). 
39. G. Dearnaley, Nature 256, 701 (1975).

40. J. Ma, Y. He, D. Wang and W. Gao, Materials Letters 58, 807 (2004).

41. J. Lindhard, M. Scharff, and H. E. Schiøtt, Konglige Danske Videnskabernes Selskab, MatematiskFysiske Meddelelser, 33, 14 (1963).

42. S. Chevalier, G. Caboche, K. Przybylski and T. Brylewski, Journal of Applied Electrochemistry 39, 529 (2009).

43. Y. Saito, B. Önay and T. Maruyama, Journal de Physique 03, (C9), 217 (1993).

44. G. Hultquist, E. Hörnlund and Q. Dong, Corrosion Science 45, 2697 (2003).

45. G. Hultquist, G. I. Sproule, S. Moisa, M. J. Graham and U. Södervall, Journal of the Electrochemical Society 150, G617 (2003). 